\title{
Blood gold concentrations in children with juvenile rheumatoid arthritis undergoing long-term oral gold therapy
}

\author{
EDWARD H. GIANNINI, EARL J. BREWER, AND DONALD A. PERSON \\ From the Rheumatology Section, Department of Pediatrics, Baylor College of Medicine, and the Rheumatology \\ Department, Texas Children's Hospital, Texas, USA
}

SUMMARY During an uncontrolled, open-labelled, open-ended clinical trial of auranofin in children with juvenile rhe umatoid arthritis (JRA) we obtained serial blood samples for the purpose of assessing gold content. Our objectives were (1) to observe the pattern of blood gold concentrations over a period of time in children undergoing long-term oral gold therapy, and (2) to observe the effect of changing dosage levels on blood gold concentrations. The initial dosage of auranofin was $0.1 \mathrm{mg} / \mathrm{kg} /$ day with allowable increases to $0.2 \mathrm{mg} / \mathrm{kg} /$ day. A concurrent nonsteroidal antiinflammatory drug was allowed. Twenty-one patients were enrolled in the study, and we obtained 2 or more serial samples on 13 of the children. At a constant dosage of $0 \cdot 1 \mathrm{mg} / \mathrm{kg} / \mathrm{day}$, steady state blood gold concentrations were attained in 11 to 13 weeks of therapy and, in the absence of a dosage change, remained remarkably constant through extended periods. The blood gold concentration was related to total daily dosage rather than to the cumulative amount of gold received. Increasing or decreasing the dose resulted in a direct effect on concentration. The clinical value of blood gold levels resulting from auranofin therapy in JRA will have to be established through double-blind controlled trials.

Gold therapy has played a major role in the longterm management of rheumatoid arthritis (RA) for almost 60 years. Historically, gold salts were given to the patient by intramuscular injection. Recently an oral gold preparation, auranofin (triethylphosphine gold, Ridaura), has become available for use in patients on an experimental basis.

In adults about $25 \%$ of the administered dose of auranofin is absorbed by the gastrointestinal tract and the half-life in the blood is approximately 21 days.' Auranofin has been found to possess definite antirheumatic properties in adult patients with RA during double-blind, controlled trials. ${ }^{23}$ In RA patients given auranofin $3 \mathrm{mg}$ twice a day (approximately $0.1 \mathrm{mg} / \mathrm{kg} /$ day) a gradual increase in the blood gold concentration was observed until the twelfth week of therapy, at which time an average level of approximately $0.7 \mu \mathrm{g}$ of $\mathrm{gold} / \mathrm{ml}$ of blood was attained. ${ }^{4}$ Concentrations in adults undergoing longterm auranofin therapy appear to plateau after about

Accepted for publication 22 March 1983.

Correspondence to Dr E. H. Giannini, Department of Pediatrics, Rheumatology Section, Baylor College of Medicine PO Box 20269, Houston, Texas 77030, USA.
12 weeks. ${ }^{1}$ Further, the plateau level is a direct function of total daily dosage. ${ }^{1}$

We have previously shown that children with juvenile rheumatoid arthritis (JRA) who received a single oral dose of auranofin equivalent to $0 \cdot 1 \mathrm{mg} / \mathrm{kg}$ attained measurable blood and serum gold concentrations. ${ }^{5}$ These concentrations ranged from a high of $0.049 \mu \mathrm{g} / \mathrm{ml}$ at 24 hours (earliest sample) to 0.0058 $\mu \mathrm{g} / \mathrm{ml}$ after 2 weeks (last sample). During a subsequent clinical trial of auranofin in children with $\mathrm{JRA}^{6}$ we obtained blood samples serially in order to observe the impact of long-term oral auranofin therapy on blood gold concentrations and the effect of changing the dosage level on blood gold concentrations.

\section{Patients and methods}

The clinical trial was designed as an uncontrolled, open-labelled, open-ended study whose principal objectives were to ascertain the safety and preliminary efficacy of auranofin at different dosage levels. The initial auranofin dosage was $0 \cdot 1 \mathrm{mg} / \mathrm{kg} /$ day, with incremental increases to as high as $0.2 \mathrm{mg} / \mathrm{kg} /$ day 
allowed. The usual increase was to $0 \cdot 15 \mathrm{mg} / \mathrm{kg} / \mathrm{day}$. Each patient also received a single nonsteroidal antiinflammatory drug (NSAID) as background medication. Permissible NSAIDs included: aspirin ( 80 $\mathrm{mg} / \mathrm{kg} /$ day or at a dosage adequate to produce a serum salicylate level of $20-30 \mathrm{mg} / \mathrm{dl})$; tolmetin sodium $(20-40 \mathrm{mg} / \mathrm{kg} /$ day); or naproxen $(400-600$ $\mathrm{mg} / \mathrm{m}^{2} /$ day).

To be included in the study patients had to meet a number of criteria. These included: (1) fulfilment of the American Rheumatism Association criteria for a diagnosis of $\mathrm{JRA}^{7} ;(2)$ age between $1 \frac{1}{2}$ and 17 years; (3) active disease not adequately controlled by NSAID alone; (4) no previous gold therapy; and (5) no steroids or slower acting antirheumatic drugs for the 3-month period immediately prior to entering the study.

In addition all patients had to have either progressive limitation of joint motion or erosive arthritis. The monitoring and follow-up of patients and monitoring for adverse reactions was as described in the Pediatric Rheumatology Collaborative Study Group (PRCSG) guidelines. $^{89}$ All patients were assessed for clinical and laboratory evidence of disease activity 2 weeks prior to the initiation of auranofin therapy, at the time therapy was begun, and at monthly intervals for the remainder of the study.

Heparinised venous blood samples were collected and sent to Smith, Kline and French Laboratories in Philadelphia for ascertainment of gold content.

GOLD ASSAY

Gold levels were determined by graphite furnace atomic absorption spectrophotometric technique. ${ }^{10}$ The specificity and versatility of similar techniques in the measurement of gold in biological material has been described elsewhere. ${ }^{11-13}$ The samples were digested by boiling in nitric and perchloric acid. They were then extracted in $25 \mathrm{ml}$ of $10 \%(\mathrm{v} / \mathrm{v})$ hydrochloric acid and saturated with methylisobutyl ketone. Standards, blanks, and test samples were included in every run. An IL Model 351 atomic absorption spectrophotometer was used to measure elemental gold.

\section{Results}

Of the 21 patients enrolled in the study 19 completed at least 4 months of treatment with auranofin. Thirteen of the 19 patients had at least 2 serial blood samples assayed for the concentration of gold. The dose received, time on the current dosage, cumulative amount of gold received, and blood gold concentrations for each patient are listed in Table 1. Eight patients had at least 3 serial samples obtained while at a constant dosage level. Their blood gold concentrations are plotted in Fig. 1. The lack of samples between 40 and 80 days does not allow a calculation of a mean time to attain steady state concentrations. However, it is reasonable to assume

Table 1 Summary of auranofin dosage, amount received, and blood concentrations

\begin{tabular}{|c|c|c|c|c|}
\hline Patient & $\begin{array}{l}\text { Dose } \\
\text { received } \\
(\mathrm{mg} / \mathrm{kg} / \text { day })\end{array}$ & $\begin{array}{l}\text { Time on } \\
\text { current } \\
\text { dosage } \\
\text { (days) }\end{array}$ & $\begin{array}{l}\text { Cumulative } \\
\text { amount of } \\
\text { auranofin } \\
\text { received } \\
(\mathrm{mg})\end{array}$ & $\begin{array}{l}\text { Blood gold } \\
\text { concentrations } \\
\mu \mathrm{g} / \mathrm{ml}\end{array}$ \\
\hline 1 & $\begin{array}{l}0 \cdot 10 \\
0 \cdot 10 \\
0 \cdot 10 \\
0 \cdot 10 \\
0 \cdot 10\end{array}$ & $\begin{array}{r}42 \\
94 \\
230 \\
416 \\
594\end{array}$ & $\begin{array}{r}196 \\
563 \\
1497 \\
2780 \\
4293\end{array}$ & $\begin{array}{l}0.33 \\
0.52 \\
0.57 \\
0.48 \\
0.47\end{array}$ \\
\hline 2 & $\begin{array}{l}0 \cdot 10 \\
0 \cdot 10 \\
0 \cdot 10\end{array}$ & $\begin{array}{r}29 \\
85 \\
172\end{array}$ & $\begin{array}{r}58 \\
168 \\
360\end{array}$ & $\begin{array}{l}0.51 \\
0.55 \\
0.49\end{array}$ \\
\hline 3 & $\begin{array}{l}0 \cdot 10 \\
0 \cdot 10 \\
0 \cdot 10\end{array}$ & $\begin{array}{r}35 \\
91 \\
228\end{array}$ & $\begin{array}{l}105 \\
240 \\
612\end{array}$ & $\begin{array}{l}0.33 \\
0.54 \\
0.51\end{array}$ \\
\hline 4 & $\begin{array}{l}0 \cdot 10 \\
0 \cdot 10 \\
0 \cdot 10\end{array}$ & $\begin{array}{r}28 \\
81 \\
190\end{array}$ & $\begin{array}{r}56 \\
160 \\
372\end{array}$ & $\begin{array}{l}0.52 \\
0.41 \\
0.63\end{array}$ \\
\hline 5 & $\begin{array}{l}0 \cdot 10 \\
0 \cdot 10\end{array}$ & $\begin{array}{l}28 \\
91\end{array}$ & $\begin{array}{r}87 \\
279\end{array}$ & $\begin{array}{l}0.26 \\
0.39\end{array}$ \\
\hline 6 & $\begin{array}{l}0 \cdot 10 \\
0 \cdot 10 \\
0 \cdot 10\end{array}$ & $\begin{array}{r}28 \\
92 \\
214\end{array}$ & $\begin{array}{r}87 \\
231 \\
613\end{array}$ & $\begin{array}{l}0.35 \\
0.59 \\
0.53\end{array}$ \\
\hline 7 & $\begin{array}{l}0 \cdot 10 \\
0 \cdot 10 \\
0 \cdot 15 \\
0 \cdot 15\end{array}$ & $\begin{array}{r}28 \\
91 \\
34 \\
188\end{array}$ & $\begin{array}{r}53 \\
163 \\
420 \\
762\end{array}$ & $\begin{array}{l}0.32 \\
0 \cdot 42 \\
0 \cdot 65 \\
0 \cdot 61\end{array}$ \\
\hline 8 & $\begin{array}{l}0 \cdot 10 \\
0 \cdot 10 \\
0 \cdot 10 \\
0 \cdot 15 \\
0 \cdot 20\end{array}$ & $\begin{array}{r}85 \\
189 \\
379 \\
126 \\
98\end{array}$ & $\begin{array}{r}169 \\
363 \\
717 \\
1433 \\
2451\end{array}$ & $\begin{array}{l}0.33 \\
0.35 \\
0.40 \\
0.74 \\
0.94\end{array}$ \\
\hline 9 & $\begin{array}{l}0 \cdot 10 \\
0 \cdot 10 \\
0 \cdot 10 \\
0 \cdot 15 \\
0 \cdot 16 \\
0 \cdot 20\end{array}$ & $\begin{array}{r}28 \\
84 \\
203 \\
27 \\
28 \\
182\end{array}$ & $\begin{array}{r}110 \\
334 \\
823 \\
1467 \\
2664 \\
4330\end{array}$ & $\begin{array}{l}0.43 \\
0.74 \\
0.46 \\
0.68 \\
0.77 \\
0.90\end{array}$ \\
\hline 10 & $\begin{array}{l}0 \cdot 10 \\
0 \cdot 10 \\
0 \cdot 10 \\
0 \cdot 15 \\
0 \cdot 12 \\
0 \cdot 12\end{array}$ & $\begin{array}{r}28 \\
82 \\
188 \\
28 \\
30 \\
204\end{array}$ & $\begin{array}{r}29 \\
84 \\
192 \\
402 \\
857 \\
1265\end{array}$ & $\begin{array}{l}0.29 \\
0.37 \\
0 \cdot 39 \\
0 \cdot 87 \\
0.08 \\
0.78\end{array}$ \\
\hline 11 & $\begin{array}{l}0.10 \\
0.07 \\
0.04 \\
0.03\end{array}$ & $\begin{array}{r}82 \\
41 \\
120 \\
80\end{array}$ & $\begin{array}{l}255 \\
539 \\
710 \\
839\end{array}$ & $\begin{array}{l}0 \cdot 78 \\
0 \cdot 42 \\
0 \cdot 18 \\
0 \cdot 21\end{array}$ \\
\hline 12 & $\begin{array}{l}0 \cdot 10 \\
0 \cdot 10 \\
0 \cdot 15\end{array}$ & $\begin{array}{r}28 \\
245 \\
200\end{array}$ & $\begin{array}{r}112 \\
936 \\
2061\end{array}$ & $\begin{array}{l}0.69 \\
0.51 \\
0.75\end{array}$ \\
\hline 13 & $\begin{array}{l}0.05 \\
0.15 \\
0.20\end{array}$ & $\begin{array}{r}21 \\
28 \\
120\end{array}$ & $\begin{array}{r}21 \\
256 \\
827\end{array}$ & $\begin{array}{l}0 \cdot 12 \\
0 \cdot 26 \\
1 \cdot 00\end{array}$ \\
\hline
\end{tabular}




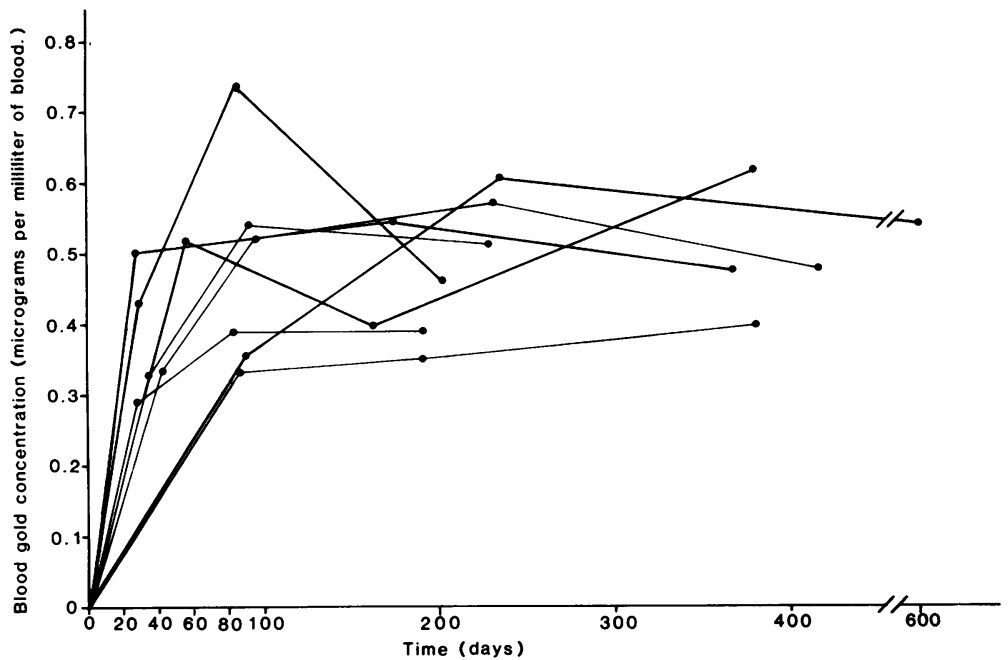

Fig. 1 Blood gold levels as a function of time in 8 patients with at least 3 samples while at a constant dosage of $0 \cdot 1 \mathrm{mg} / \mathrm{kg} /$ day. that steady state was reached in the majority of these children by at least 80 to 90 days and perhaps even earlier in some. In the 11 patients who had blood samples obtained between 11 and 13 weeks while at a constant dosage of $0 \cdot 1 \mathrm{mg} / \mathrm{kg} /$ day the average steady state concentration was $0.51 \mu \mathrm{g} / \mathrm{ml}$ of blood (SEM = $0.044)$. In addition at a constant dosage the concentrations remained virtually unchanged.

In all cases increasing or decreasing the dosage of auranofin resulted in a corresponding change in blood gold concentration. As we have reported previously, ${ }^{6}$ patients who received the higher dose tended to do better with respect to clinical improvement and laboratory parameters of disease activity. Owing to the uncontrolled nature of this trial and the lack of uniformity in regard to the time at which blood samples were obtained for assay of gold content no effort has been made to correlate directly blood gold concentration with therapeutic efficacy.

\section{Discussion}

Data from the current study are remarkably similar to those obtained from studies of auranofin's pharmacokinetics in adults. ${ }^{1}$ It appears that auranofin produces much more constant blood gold levels than do parenterally administered gold salts. ${ }^{14}$ However, the therapeutic consequences of this observation remain to be assessed. Moreover blood gold concentrations resulting from injectable gold are many times higher than those obtained with oral auranofin. However, it is well established that gold concentrations resulting from parenterally administered compounds correlate poorly with clinical efficacy. ${ }^{15-17} \mathrm{~A}$ possible explanation for this lack of correlation is that the minimum, or threshold concentration at which gold becomes effective may have been exceeded many fold in these patients, and changes above this threshold have little impact on therapeutic outcome. Possibly some measureable lower boundary for efficacy exists in auranofin treated patients in whom steady state concentrations are measured in units as small as tenths of micrograms per millilitre of blood.

Animal and adult human studies of auranofin indicate that the chemical and physical properties, invivo distribution, and pharmacological mechanisms of action differ from those of the injectable gold compounds now in use..$^{1418}$ Thus the search for a minimum therapeutic range of blood gold concentration resulting from auranofin should not be immediately disregarded. We are unaware of published studies that have attempted to establish such a minimum therapeutic level in the adult. If such data do become available for RA, generalisation to JRA will probably not be possible, since it may be argued that, although the articular manifestations are similar, the underlying disease processes may be different. It will be necessary to study children with JRA treated with auranofin for minimum therapeutic levels, preferably in a double-blind trial.

Computational assistance was provided by the CLINFO project funded by Grant RR-00350, Division of Research Resources, National Institutes of Health.

We thank Mrs Anne Pratt and Mrs Sally Leighton for their assistance in the data analysis and preparation of this manuscript.

\section{References}

1 Gottlieb N L. Comparative pharmacokinetics of parenteral and oral gold compounds. J Rheumatol 1982; 9 (suppl 8): 99-109. 
2 Katz W A, Alexander S, Bland J H, et al. The efficacy and safety of auranofin compared to placebo in rheumatoid arthritis. $J$ Rheumatol 1982; 9 (suppl 8): 173-8.

3 Schattenkirchner M, Kaik B, Muller-Fassbender $\mathrm{H}$, et al. Auranofin and sodium aurothiomalate in the treatment of rhe umatoid arthritis - a double-blind, comparative, multicenter study.J Rheumatol 1982; 9 (suppl 8): 184-9.

4 Berglof F E, Berglof K, Walz D T. Auranofin: an oral chrysotherapeutic agent for treatment of rheumatoid arthritis. $J$ Rheumatol 1978; 5: 68-74.

5 Giannini E H, Person D A, Brewer E J, et al. Blood and serum concentrations of gold after a single dose of auranofin in children with juvenile rheumatoid arthritis(JRA).J Rheumatol 1983; 10.

6 Giannini E H, Brewer E J, Person D A. Auranofin in the treatment of juvenile rheumatoid arthritis. J Pediatr 1983; 102: 138-41.

7 Brewer E J, Bass J, Baum J, et al. Current proposed revision of JRA criteria. Arthritis Rheum 1977; 20: 195-9.

8 Brewer E J, Giannini E H. Standard methodology for segments I, II, and III pediatric rheumatology collaborative study group studies: I. Design.J Rheumatol 1982; 9: 109-13.

9 Giannini E H, Brewer E J. Standard methodology for segments I, II, and III pediatric rheumatology collaborative study group studies: II. Analysis and presentation of data.J Rheumatol 1982; 9: 114-22.

10 Bumbier E E, Johnson W P, Holl W W, et al. Gold assay of biological samples to two parts per billion with a digestionextraction-graphite furnace atomic absorption procedure. Proc Fed Analytical Chem Spectroscopy Soc 1980; 342.
11 Harth M, Haines D S M, Bondy D C. A simple method for the determination of gold in serum, blood, and urine by atomic absorption spectroscopy. Am J Clin Pathol 1973; 59: 423-8.

12 Kamel H, Brown D H, Ottaway J M, et al. Determination of gold in blood fractions by atomic-absorption spectrometry using carbon rod and carbon furnace atomisation. Analyst 1976; 101: 790-7.

13 Kamel H, Brown D H, Ottaway J M, et al. Determination of gold in separate protein fractions of blood serum by carbon furnace atomic absorption spectrometry. Analyst 1977; 102: 645-57.

14 Walz D T, DiMartino M J, Griswold D E, et al. Comparative pharmacology and biological effects of different gold compounds. J Rheumatol 1982; 9 (suppl 8): 54-60.

15 Gerber R C, Paulus H E, Bluestone R, et al. Clinical response and serum gold levels in chrysotherapy-lack of correlation. Ann Rheum Dis 1972; 31: 308-10.

16 Levinson J E, Balz G P, Bondi S. Gold therapy. Arthritis Rheum 1977; 20: 531-5.

17 Sharp J T, Lidsky M D, Duffy J, et al. Comparison of two dosage schedules of gold salts in the treatment of rheumatoid arthritis: relationship of serum gold levels to therapeutic response. Arthritis Rheum 1977; 20: 1179-87.

18 Sadler $P$ J. The comparative evaluation of the physical and chemical properties of gold compounds. J Rheumatol 1982; 9 (suppl 8): 71-8.

19 Herrlinger J D, Alsen C, Beress R, et al. Distribution of gold in serum erythrocytes and white blood cells after in vitro incubation and during chrysotherapy with different gold compounds. $J$ Rheumatol 1982; 9 (suppl 8): 81-9. 